\title{
Reducing the Phytoplankton Biomass to Promote the Growth of Submerged Macrophytes by Introducing Artificial Aquatic Plants in Shallow Eutrophic Waters
}

\author{
Yue $\mathrm{Wu}^{1,2}$, Licheng Huang ${ }^{1}$, Yalin Wang ${ }^{1}$, Lin $\mathrm{Li}^{1}{ }^{1} * \mathbb{C}$, Genbao $\mathrm{Li}^{1}{ }^{1}$, Bangding Xiao ${ }^{1}$ \\ and Lirong Song 1 \\ 1 State Key Laboratory of Freshwater Ecology and Biotechnology, Key Laboratory of Algae Biology, Institute \\ of Hydrobiology, Chinese Academy of Sciences, Wuhan 430072, China \\ 2 University of Chinese Academy of Sciences, Beijing 100049, China \\ * Correspondence: lilin@ihb.ac.cn; Tel.: +86-27-6878-0037
}

Received: 23 April 2019; Accepted: 29 June 2019; Published: 2 July 2019

check for updates

\begin{abstract}
Harmful cyanobacterial blooms frequently occur in shallow eutrophic lakes and usually cause the decline of submerged vegetation. Therefore, artificial aquatic plants (AAPs) were introduced into enclosures in the eutrophic Dianchi Lake to investigate whether or not they could reduce cyanobacterial blooms and promote the growth of submerged macrophytes. On the 60th day after the AAPs were installed, the turbidity, total nitrogen (TN), total phosphorous (TP), and the cell density of phytoplankton (especially cyanobacteria) of the treated enclosures were significantly reduced as compared with the control enclosures. The adsorption and absorption of the subsequently formed periphyton biofilms attached to the AAPs effectively decreased nutrient levels in the water. Moreover, the microbial diversity and structure in the water changed with the development of periphyton biofilms, showing that the dominant planktonic algae shifted from Cyanophyta to Chlorophyta. The biodiversity of both planktonic and attached bacterial communities in the periphyton biofilm also gradually increased with time, and were higher than those of the control enclosures. The transplanted submerged macrophyte (Elodea nuttallii) in treated enclosures recovered effectively and reached $50 \%$ coverage in one month while those in the control enclosures failed to grow. The application of AAPs with incubated periphyton presents an environmentally-friendly and effective solution for reducing nutrients and controlling the biomass of phytoplankton, thereby promoting the restoration of submerged macrophytes in shallow eutrophic waters.
\end{abstract}

Keywords: artificial aquatic plants; periphyton biofilm; cyanobacteria; eutrophication; Dianchi Lake

\section{Introduction}

The principal characteristics of aquatic macrophytes are their ability to accumulate nutrients and sustain biogeochemical cycles in aquatic environments [1,2]. However, shallow lake eutrophication with the concomitant occurrence of cyanobacterial blooms has led to the decline of submerged macrophytes and the degeneration of water functions [3,4], which have transformed from a macrophyte-dominated state (clear water state) to a phytoplankton-dominated state (turbid water state) [5,6]. Environmental stressors, such as nutrient enrichment [7], high temperatures [8], and water level changes [9], favor cyanobacterial communities. Additionally, previous studies have reported that the low light intensity in many fertile lakes was associated with low submerged macrophyte productivity [10,11]. Therefore, the determination of an appropriate approach as a transitional means of creating beneficial conditions that control cyanobacterial blooms and restore macrophytes is urgently needed.

Many strategies have been proposed to alleviate the effects of cyanobacterial blooms, including the application of aluminum sulphate to decrease phosphorus concentrations through the reaction of 
co-precipitated phosphorus into the sediment [12]. Inorganic compounds in marl have been used to immobilize nutrients on the sediment surface, thus reducing nutrient concentrations in the water [13]. However, the aforementioned methodologies often have some effect on the original aquatic ecosystem, including changes in $\mathrm{pH}$ or salinity, which may threaten life in the lake [14]. Other measures have been applied to control the cyanobacterial blooms directly. Algaecides such as organic bromide, copper sulphate, and hydrogen peroxide have mostly been used to control large-scale cyanobacterial bloom as an emergency method, but these may result in an unsafe aquatic ecosystem and easily induce secondary pollution [15].

Periphyton is an assemblage of freshwater organisms mainly composed of photoautotrophic algae, heterotrophic, and chemoautotrophic bacteria, fungi, protozoans, metazoans and viruses, which attach to submerged surfaces [16]. Periphyton plays a crucial role in nutrient cycling and in supporting food webs and it has an excellent ability to degrade pollutants in aquatic environments [17]. Previous studies have utilized biofilms to remove nitrogen and phosphorus from wastewater and to biodegrade other hazardous contaminants $[18,19]$. Moreover, microbial communities are easily incorporated into bioreactors, which result in efficient bioremediation operations [20]. Additionally, the microbial compositions of periphyton are derived from original habitats, which prevent changes to the original community from occurring. On the basis of these properties, immobilizing the periphyton on artificial substrates and suspending it between the sediment and overlying water allows periphyton to serve as an advantageous approach for controlling contaminants in aquatic environments [21]. The artificial aquatic plant (AAP) was chosen as the most efficient for improving water quality among four different substrates (aquamats, biocompatibility carbon fiber, eco-carbon fiber, and AAP) based on our previous studies. The results demonstrated that both biocompatibility carbon fiber and the AAP improve water quality by reducing the concentration of nutrients of experiment water which restrained the reproduction of algae in the water column. The removal rates of TN, TP, and Chl- $a$ by AAP and biocompatibility carbon fiber were: $66.81 \%, 61.85 \% ; 57.89 \%, 8.26 \%$; and $88.84 \%, 94.03 \%$ respectively [22]. Comprehensively, taking in to consideration the cost performance and construction convenience, the AAP was a more favorable material, with longevity over 15 years, for the application in the ecological restoration of shallow eutrophic waters. Due to the structure of plentiful micropores between the microfibers ( $8.5-9.0 \mathrm{~cm}$ per microfiber), the periphyton is provided with adhesive surfaces of $8000 \mathrm{~m}^{2} / \mathrm{m}^{3}$, and results in strong adsorption and absorption.

Research concerning periphyton has predominantly focused upon the purifying capacity of periphyton in bioreactors and rivers $[23,24]$, while studies in eutrophic lakes remain rare $[25,26]$. Taking the periphyton biofilm as an assemblage, there is a need to understand the performance and processes involved with algal-bacterial biofilm-based wastewater treatment projects. In this study, we employ periphyton biofilms with artificial substrates to alleviate the negative effects of phytoplankton biomass on aquatic conditions in shallow eutrophic waters, and we explore whether or not this biological measure provides a transition for the restoration of submerged macrophytes. The main objectives of this study are (i) evaluation of nutrient removal performance and impacts on the microbial community, (ii) investigation of the dynamics of periphyton attached on artificial substrates during the experiment, and (iii) discussion of the possible role of periphyton to control cyanobacterial blooms.

\section{Materials and Methods}

\subsection{Study Site}

Dianchi Lake $\left(24^{\circ} 51^{\prime} \mathrm{N}, 102^{\circ} 42^{\prime}\right.$ E, Figure 1) located on a plateau in southwestern China, has a water surface of $300 \mathrm{~km}^{2}$, watershed area of $2920 \mathrm{~km}^{2}$, and an altitude of $1886.5 \mathrm{~m}$ above sea level [27]. Since the establishment of Haigeng Dam in 1996, Lake Dianchi has been separated into two parts: Caohai in the north with a water surface of $11 \mathrm{~km}^{2}$ and average water depth of $2.5 \mathrm{~m}$ and Waihai in the south with a water surface of $299 \mathrm{~km}^{2}$ and average water depth of $5 \mathrm{~m}$. The map of Dianchi Lake watershed is modified from Wang et al. [28]. Due to the rapid economic development and intensive 
use of the water resources, the water in this lake has become seriously polluted, and cyanobacterial blooms have occurred frequently in the past 20 years [29]. In this study, the experimental enclosures were built in Caohai Bay $\left(24^{\circ} 58^{\prime} \mathrm{N}, 102^{\circ} 38^{\prime} \mathrm{E}\right)$ which were located in the north of Lake Dianchi.

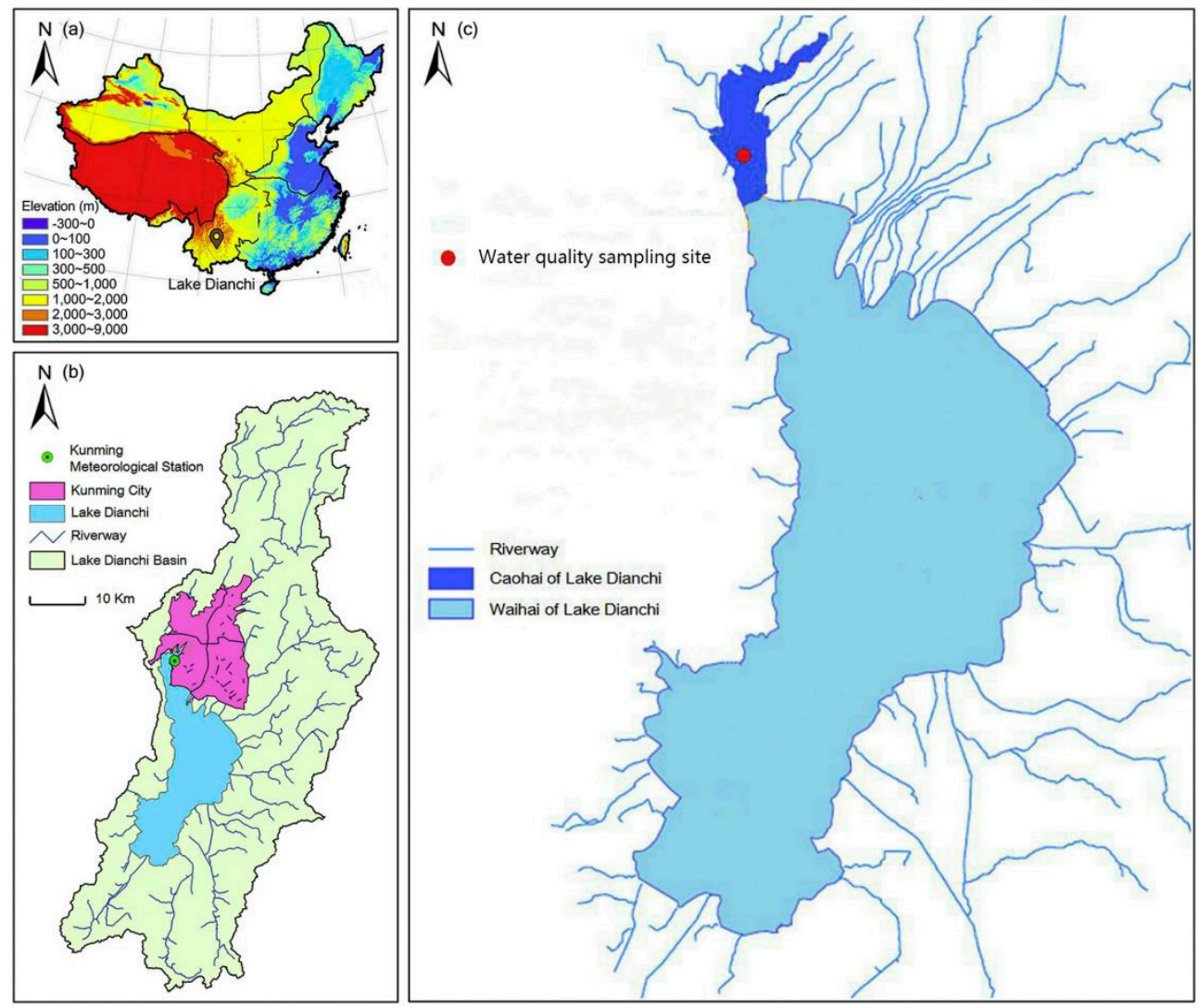

Figure 1. Map of Dianchi Lake watershed.

\subsection{Experimental Design}

Four enclosures (each $6 \mathrm{~m} \times 6 \mathrm{~m} \times 2 \mathrm{~m}$, length $\times$ width $\times$ height, Figure 2) were constructed with rubber cloth (around all sides of the water column) and geotextile (underwater). They were open to the air and above the sediment at the bottom of Caohai Bay. Two enclosures were used as the control enclosure and the others employed fresh artificial aquatic plants (AAPs). The AAP strand (Figure 2) was composed of thousands of polypropylene microfibers, which imitate the structure of natural aquatic plants. A uniform weight was used for cement balls tied at the bottom of every strand of the AAP to maintain a vertical state and set a density of 1 strands $/ \mathrm{m}^{3}$ in the treatment enclosures. 
A

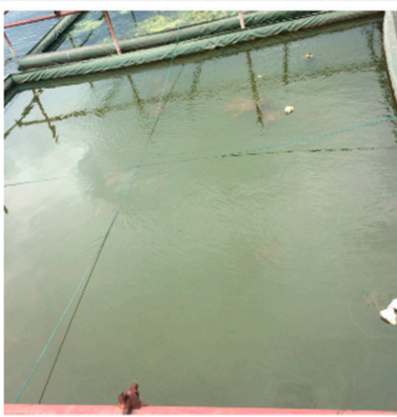

$\mathbf{C}$

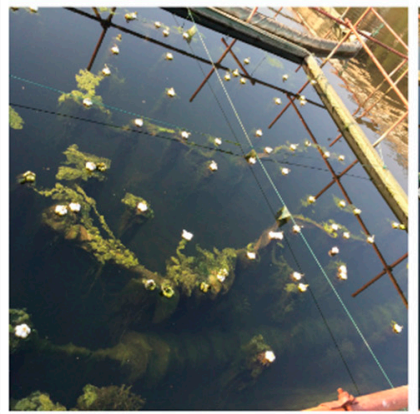

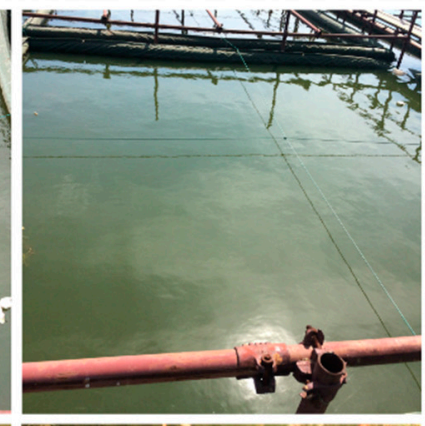

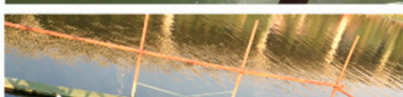

B

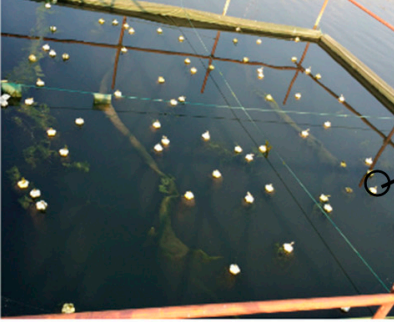

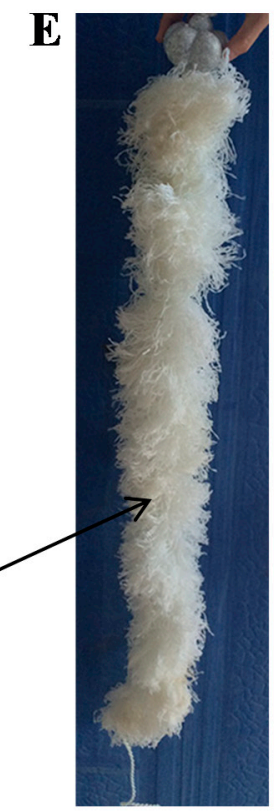

Figure 2. Experimental setup of the enclosures and structure of the (E) artificial aquatic plant (AAP); $(\mathbf{A}, \mathbf{B})$ control enclosures; (C,D) treated enclosures with 1 strand AAP $/ \mathrm{m}^{3}$ with length of $80-85 \mathrm{~cm}$.

\subsection{Sample Preparation}

Representative microfibers, which contained periphyton biofilms, were removed from the AAP at different times. To assure vertical comparability, both the samples of water and microfibers of AAP were collected at a depth of $0.5 \mathrm{~m}$ during the experiment. For eliminating spatial heterogeneity, the water samples were collected at three sampling sites horizontally in the same enclosure and twice a month. Similarly, the microfiber samples were carefully cut from three different AAP strands in the same enclosure with sterile scalpels and then weighed for microbial analyses once per month.

\subsection{Environmental Parameters}

The performance of experimental enclosures was evaluated by comparing water quality indices during this experiment. Chemical oxygen demand (COD), total nitrogen (TN), and total phosphorus (TP) were determined according to the standard methods for water and wastewater monitoring and analysis [30]. The water temperature (WT), dissolved oxygen (DO), and $\mathrm{pH}$ were measured in situ via a multiparameter sonde (EXO 2, YSI Inc., Yellow Springs, OH, USA). Water transparency (SD) was measured with a $10 \mathrm{~cm}$ diameter black and white Secchi disk. The chlorophyll-a (Chl $a)$ content of the water was determined after extraction of the filtered algal mat with $90 \%$ acetone as per AHPA [31]. Phytoplankton were identified and counted using the methods described by $\mathrm{Hu}$ et al. [32].

\subsection{Phytoplankton Community and Total Phosphorous (TP) Associated with Periphyton Biofilms}

After clearing microfibers of AAPs with distilled water, attached phytoplankton cells were extracted from the microfibers using a modified soil extraction method [33]. Briefly, $20 \mathrm{~mL}$ of a sterile saline solution was added to $0.5 \mathrm{~g}$ textile (dry weight) in $50 \mathrm{~mL}$ centrifugation tubes. After centrifuging for $2 \mathrm{~min}$ at a maximum speed (Vortex Genie2, Scientific Industries, Inc., Bohemia, NY, USA), the sample was shaken horizontally at $200 \mathrm{rpm}$ for $30 \mathrm{~min}$ at room temperature. This process was repeated three times and the algal fluid volume was collected and used to measure the Chl $a$ by spectrophotometry [34] and count the cell density of attached algae by microscopy [32].

To compare the dynamics of planktonic algae in the water column with algae attached to the $\mathrm{AAP}$, the conversional relationship was examined using the volume of each enclosure $\left(72 \mathrm{~m}^{3}\right)$ and 
the density of the AAPs ( 2 strands $/ \mathrm{m}^{2}$ ) in each enclosure (mean 72 strands/enclosure).The formula for the Chl $a$ content adsorbed by the whole AAP in each enclosure, is given as Equation (1) and the cell density of the attached algae is defined by Equation (2). The content of the TP adsorbed by the periphyton biofilms attached to the microfibers of the AAP was measured by a modified method using the TP in the sediment. The periphyton biofilms were removed from the microfibers of the AAPs using distilled water and ash was formed at $450{ }^{\circ} \mathrm{C}$ in a muffle furnace with an acid dissolution [35].

To compare the concentration of the TP in the water column with that in the periphyton biofilms, the conversional relationship was examined using the TP content adsorbed by the periphyton biofilms attached to microfibers of AAPs in each enclosure, as defined by Equation (3).

$$
\begin{gathered}
\mathrm{A}_{1}=\frac{\mathrm{A}_{2} \times \mathrm{V}_{1} \times \mathrm{M}_{2} \times 72}{\left(72000 \times \mathrm{M}_{1}\right)} \\
\mathrm{B}_{1}=\frac{\mathrm{B}_{2} \times \mathrm{V}_{1} \times \mathrm{M}_{2} \times 72}{\left(72000 \times \mathrm{M}_{1}\right)} \\
\mathrm{C}_{1}=\frac{\mathrm{M}_{2} \times \mathrm{C}_{2} \times 72}{72000}
\end{gathered}
$$

where, $A_{1}$ is the content of $\mathrm{Chl} a$ adsorbed by all strands of the AAPs in each enclosure; $\mu \mathrm{g} / \mathrm{L}, \mathrm{A}_{2}$ is the content of $\mathrm{Chl} a$ adsorbed by microfibers of the AAP; $\mu \mathrm{g} / \mathrm{L}, \mathrm{B}_{1}$ is the cell density of attached algae for all strands of the AAPs in each enclosure; and cells/L and $B_{2}$ is the cell density of attached algae by microfibers of the AAP, cells/L. Additionally, $\mathrm{C}_{1}$ is the TP content adsorbed by periphyton biofilms attached to all strands of the AAPs in each enclosure; $\mathrm{mg} / \mathrm{L}, \mathrm{C}_{2}$ is the TP content adsorbed by periphyton biofilms attached to the quantitative microfibers of the $A A P, m g / g ; M_{1}$ is the dry weight of microfibers of the AAP, $g ; M_{2}$ is the average dry weight per strand of the AAP, g; $V_{1}$ is the algal fluid volume collected from the microfibers of the AAP, L; 72 is the number of AAPs of each enclosure, and strand and 72,000 is the volume of each enclosure, $\mathrm{L}$.

\subsection{DNA Extraction and Sequencing}

Quantitative microfibers that contained periphyton biofilms for the sequencing of $16 \mathrm{~S}$ ribosomal RNA (rRNA) gene amplicons were first processed as follows: DNA was extracted, 16S rRNA gene polymerase chain reaction (PCR) amplification was performed, and PCR products were purified. For DNA extraction, $100 \mathrm{~mL}$ water samples were filtered by cellulose acetate filters (pore size $=0.2 \mathrm{~mm}$, diameter $=45 \mathrm{~mm}$, XingYa, Shanghai, China) and DNA was isolated from the filters, and directly from $0.2 \mathrm{~g}$ of biocarrier using the FastDNA kit (MP Biomedicals, Santa Ana, California, USA) and the FastPrep instrument (Savant Instruments, Inc., Holbrook, NY, USA) according to their protocols. The 16S rRNA genes were amplified using bacterial universal primers 27F (AGRGTTTGATCMTGGCTCAG) and 1492R (GGTTACCTTGTTACGACTT), DNA dilutions were used as a template, and PCR was conducted with a volume of $20 \mu \mathrm{L}$, with $10 \mu \mathrm{L}$ of PCR master mix, $8 \mu \mathrm{L}$ of sterile water, $0.5 \mu \mathrm{L}$ each of forward and reverse primers, and $1 \mu \mathrm{L}$ of the template DNA ( 100 ng). Amplification used the following protocol: initial denaturation at $95^{\circ} \mathrm{C}$ for $1 \mathrm{~min}$, followed by 40 cycles of $95^{\circ} \mathrm{C}$ for $25 \mathrm{~s}, 53^{\circ} \mathrm{C}$ for $30 \mathrm{~s}$, and $70^{\circ} \mathrm{C}$ for $60 \mathrm{~s}$; the samples were amplified in triplicate. The PCR products were then subjected to sequence analysis (Nuohe, Beijing, China).

\subsection{Submerged Macrophyte—Elodea Nuttallii}

In order to explore the feasibility of periphyton, biofilms attached on the AAPs to increase the transparency and incident light, thereby facilitating the growth of submerged macrophytes. Prepared $30 \mathrm{~cm}$ high seedlings of the submerged macrophyte, Elodea nuttallii, which can grow slightly even in winter if the daily mean water temperature is higher than $4{ }^{\circ} \mathrm{C}[36,37]$, were wrapped with loess clay and nonwoven fabrics and were arranged to transplant into all experimental enclosures at suitable conditions. 


\subsection{Data Analysis}

Nutrient concentrations were expressed as the means \pm standard deviation of duplicates $(3 \times 2)$. Because normality and homogeneity of variance assumptions were not satisfied, we used the nonparametric Kruskal-Wallis test followed by the Nemenyi test (post hoc test) to test whether the time phases or (interaction) installed AAPs have differences or similarities between two groups in each time phase, with PASW Statistics 20 (SPSS Inc., Hong Kong, China). The significance level was $p=0.05$. Amplicon sequence analysis was performed using QIIME Pipeline Version 1.7.0 (Nuohe, Beijing, China) [38] and the weighted UniFrac distance for the unweighted pair group method with arithmetic mean (UPGMA), sample clustering tree, and principle coordinates analysis (PCoA).

\section{Results and Discussion}

\subsection{Variation of Water Quality in the Enclosures}

During the experiment, water temperature ranged between $13.1{ }^{\circ} \mathrm{C}$ and $15.6^{\circ} \mathrm{C}$. In control enclosures, turbidity decreased from $11.40( \pm 1.70)$ nephelometric turbidity units (NTU, Figure 3A) to $6.85( \pm 0.30)$ NTU by day 60 . In treatment (i.e., within AAPs) enclosures, turbidity decreased from $10.80( \pm 2.04)$ NTU to $3.13( \pm 0.77)$ NTU by day 60 . Water turbidity in control enclosures was significantly higher $(p<0.05)$ than that of treatment enclosures within the AAPs throughout the experiment after 60 days of operation. The concentration of COD (Figure 3B) declined from $12.06( \pm 1.35) \mathrm{mg} / \mathrm{L}$ to $4.04( \pm 0.037) \mathrm{mg} / \mathrm{L}$ and to $2.11( \pm 0.25) \mathrm{mg} / \mathrm{L}$ in the control and treatment enclosures, respectively; there was no significant difference between the enclosures $(p>0.05)$. Total nitrogen (Figure 3C) declined from 0.96 to $0.41 \mathrm{mg} / \mathrm{L}$ in treatment enclosures over 60 days, while TN slowly decreased from 0.96 to $0.90 \mathrm{mg} / \mathrm{L}$ in the first month and then gradually increased to $0.94 \mathrm{mg} / \mathrm{L}$ in the control enclosures. Jiang et al. measured total nitrogen removal of $92 \%$ by using a hybrid biofilm reactor [39]. Total phosphorous (Figure 3D) decreased from $0.067( \pm 0.002) \mathrm{mg} / \mathrm{L}$ to $0.051 \mathrm{mg} / \mathrm{L}$ and to $0.033 \mathrm{mg} / \mathrm{L}$ in the control and treatment enclosures, respectively. Water TP in control enclosures was significantly higher $(p<0.05)$ than that of treatment enclosures within the AAPs after 60 days of operation; the removal efficiency later exceeded $50 \%$. Sukačová et al. reported a P removal efficiency of $99 \%$ within 24 hours of $\mathrm{P}$ addition when using an algal biofilm [40]. Chlorophyll a was used as an indicator of algal biomass (Figure 3E). In control enclosures, $\mathrm{Chl} a$ slightly declined from 285.46 ( \pm 22.66$)$ to 177.65 $( \pm 2.42) \mu \mathrm{g} / \mathrm{L}$ by day 60 , while the $\mathrm{Chl} a$ of treatment enclosures decreased from $283.17( \pm 36.01) \mu \mathrm{g} / \mathrm{L}$ to $43.82( \pm 6.34) \mu \mathrm{g} / \mathrm{L}$ by day 60 , which was significantly lower than that of control $(p<0.05)$ enclosures after 30 days of operation; the removal efficiency exceeded $80 \%$.The results suggest the feasibility of using AAPs to reduce nutrient concentrations and algal biomass in eutrophic waters. The biophysical adsorption of phytoplankton by the microfibers and its adherent periphyton biofilms may contribute to the uptake, storage, and transformation of nutrients, as well as other chemicals, which play a key role in the self-purification of water bodies [41].
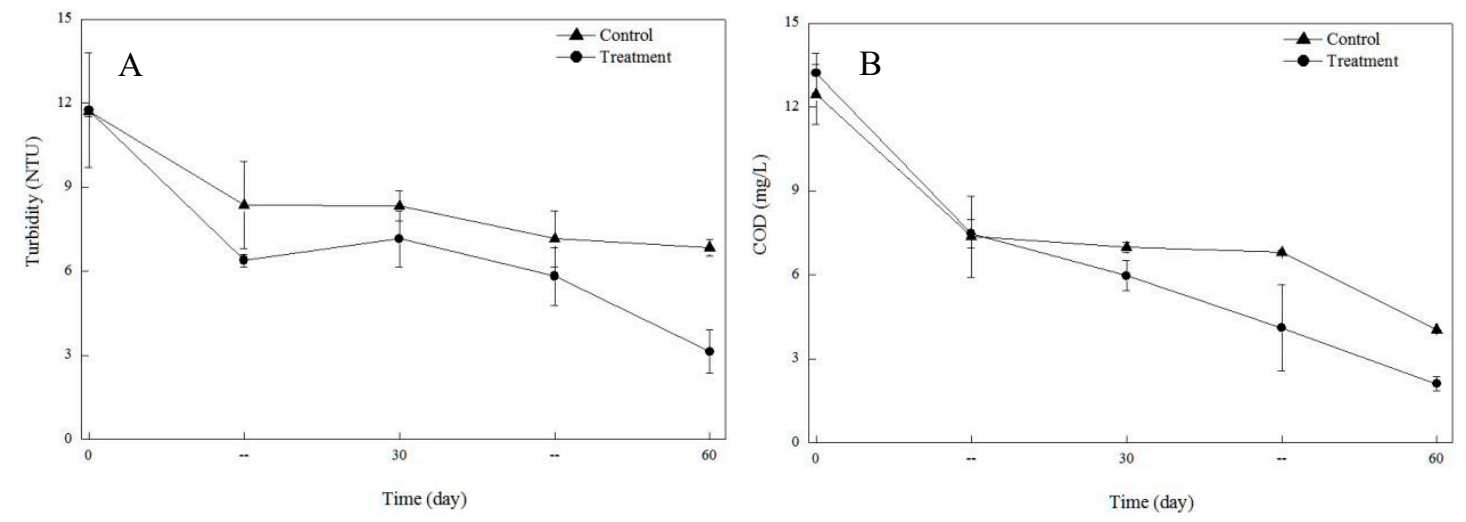

Figure 3. Cont. 

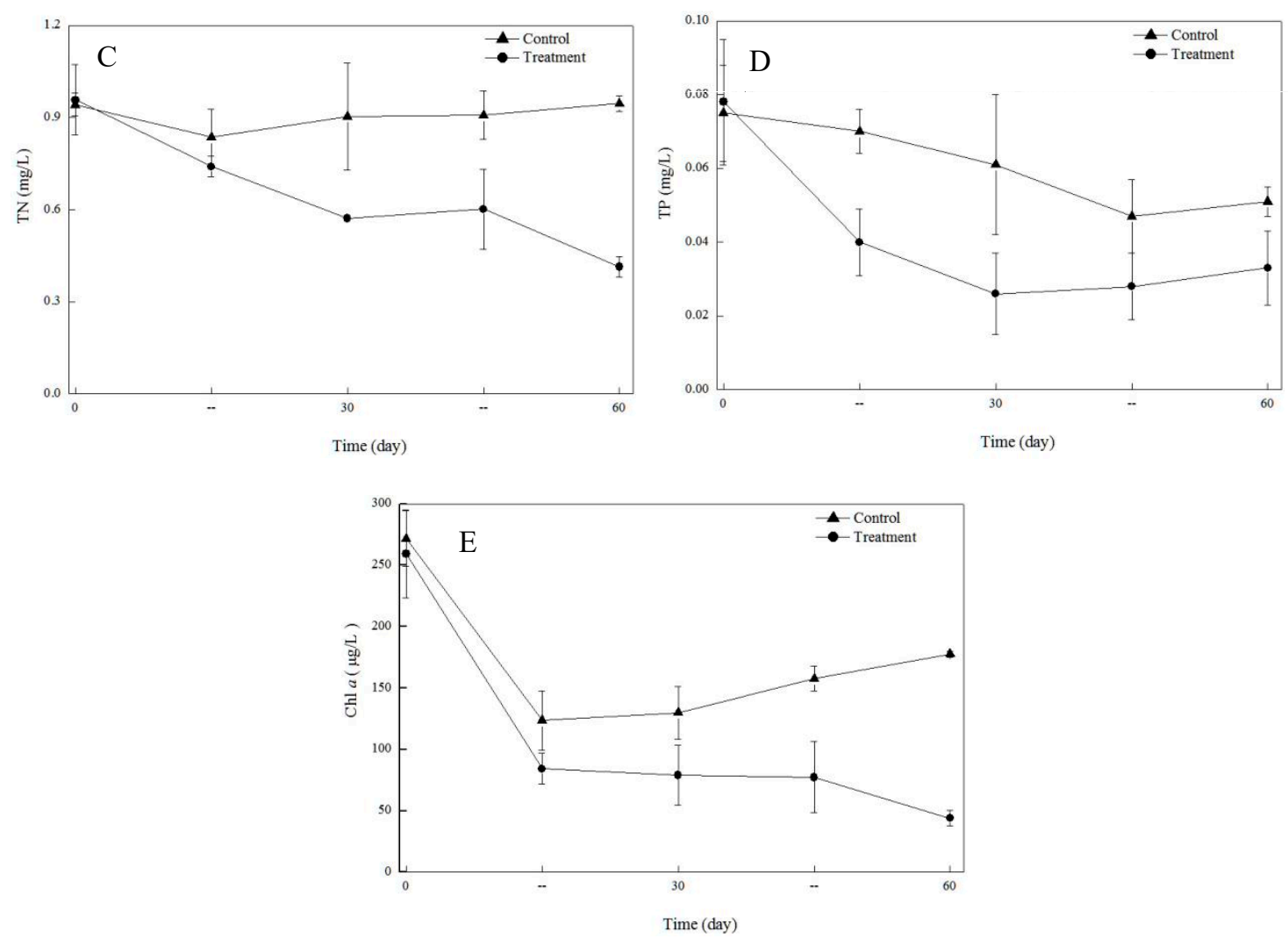

Figure 3. (A) turbidity, (B) chemical oxygen demand (COD), (C) total nitrogen (TN), (D) total phosphorous (TP) and (E) chlorophyll a (Chl a) content in the water column over 60 days. Error bars represent the standard deviation $(n=3 \times 2)$.

\subsection{Variation of TP Concentrations in Periphyton Biofilms Attached to Artificial Aquatic Plants (AAPs)}

Compared to the average, dry weight per strand of AAP weighed $75( \pm 4.2) \mathrm{g}$. The mean dry weight per strand of AAP ranged from $87.3( \pm 5.1) \mathrm{g}$ to $100.8( \pm 4.2) \mathrm{g}$ from day 30 to day 60 . According to the relationship expressed in Equation (3), the TP content adsorbed by periphyton biofilm attached to the AAPs ranged from $0.03( \pm 0.004) \mathrm{mg} / \mathrm{L}$ to $0.04( \pm 0.004) \mathrm{mg} / \mathrm{L}$ from day 30 to day 60 of the experiment. The resulting TP content in the water column was significantly decreased while that in the periphyton biofilms gradually increased in the same enclosure, which indicates that the cumulative adsorption and absorption by extensive periphyton biofilms attaching to AAPs played an important role in nutrient migration. Previous studies have reported that periphyton biofilms have a strong affinity for removing phosphorus, and therefore constitute an effective phosphorus sink [42]. This may be attributed to the uptake and transformation of biologically available soluble phosphorus for self-growth [43].

\subsection{Dynamics of Phytoplankton in Water Column with the Development of Periphyton Biofilms Attached} to $A A P S$

In this study, we investigated the biomass and composition of phytoplankton communities, which covered the water and microfibers of AAPs. Three types of samples were compared: (i) water samples from control enclosures without AAPs (CW), (ii) water samples from treatment enclosures within AAPs (TW), and (iii) microfiber samples containing periphyton biofilm attached to AAPs (TB) from treatment enclosures. The samples were then classified according to their different time phases.

The cell density of algae was driven mainly by the total phytoplankton and the cyanobacteria in all enclosures (Figure 4). Compared to the control enclosure, the mean cell density of total planktonic algae in the TW decreased rapidly from $1.09 \times 10^{8}\left( \pm 0.32 \times 10^{8}\right)$ cells/L to $0.15 \times 10^{8}\left( \pm 0.04 \times 10^{8}\right)$ cells/L, and the Chl $a$ of TW declined at a rate of over $80 \%$ after 60 days of this experiment. Additionally, 
the mean cell density of cyanobacteria showed a similar trend and declined quickly from $6.0 \times 10^{7}$ $\left( \pm 1.91 \times 10^{7}\right)$ cells/L to $0.5 \times 10^{7}\left( \pm 0.22 \times 10^{7}\right)$ cells/L. After 30 days of operation, the cell density of total planktonic algae in the TW1 was significantly lower than that of CW1 $(p<0.05)$. These results suggest that the phytoplankton were inhibited, obviously in the enclosures with AAP treatments, with respect to the control enclosure. Interestingly, it was found that the cell density of the total adherent algae in the TB amounted to $5.6 \times 10^{7}\left( \pm 0.40 \times 10^{7}\right)$ cells/L after 60 days of operation, and this included the cell density of cyanobacteria, which summed to $1.5 \times 10^{7}\left( \pm 0.90 \times 10^{7}\right)$ cells/L with the extension of incubation time. On the basis of the measurements of the microfibers of AAPs and the given conversion formula, the concentration of $\mathrm{Chl} a$ by periphyton biofilms attached to AAPs increased to $94.8( \pm 5.48) \mu \mathrm{g} / \mathrm{L}$. As substrata, the microfibers of AAPs provided a rough and porous surface that promoted higher planktonic micro-algal cell attachment. Therefore, with respect to adsorption, pioneer planktonic algal cells attached to the substrata and biological adhesion continued to form micro-colonies. In addition, the attachment of microalgal cells to a stable surface increased their abundance relative to the water column, which made them communicate and protect each other to adapt to environmental conditions [44].

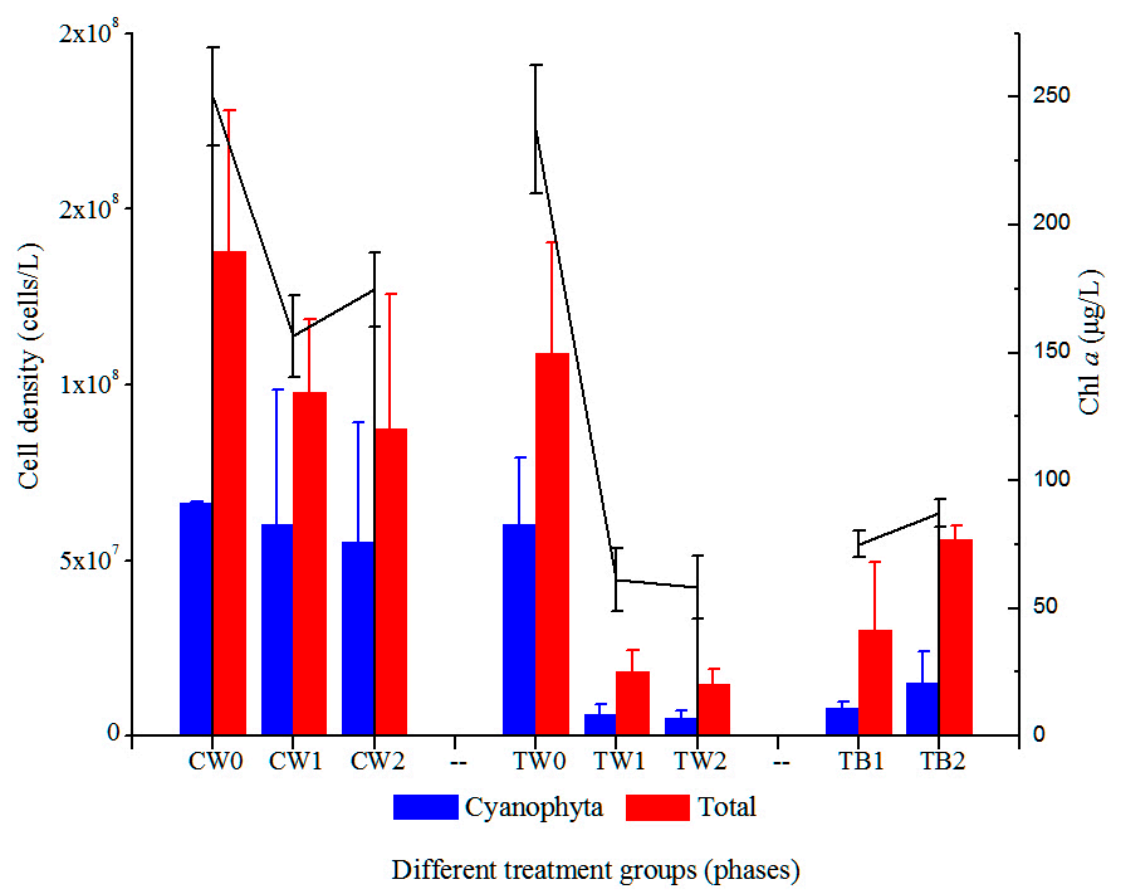

Figure 4. Variation of cell density relative to total algae (including cyanobacteria), and the corresponding concentration of $\mathrm{Chl} a$ (shown as black line) in all enclosures. Error bars represent standard deviation $(\mathrm{n}=3 \times 2)$. Designations 0,1 , and 2 represent days 0,30 , and 60 , respectively.

The aforementioned results, combined with the TP content resided in periphyton biofilms, may suggest that competition occurs between periphyton and planktonic algae, including cyanobacteria, for the phosphorus that algal cells require for growth. Some studies have shown that periphyton biofilms competed with planktonic algae for mutual resources, such as nutrients and space $[45,46]$. These results indicate the feasibility of the AAPs to reduce nutrient loads in water bodies and the phytoplankton biomass.

The structural composition of phylum-level algae was exhibited through the relative abundances (Figure 5). With the extension of experimental time, the proportion of cyanobacteria that consistently dominated and occupied more than $50 \%$ of the habitat reached $71.7 \%$ in the CW. In the TW, the dominant phylum was Cyanophyta at the initial stage and then shifted to Chlorophyta. Specifically, the proportion of Cyanophyta declined rapidly from $63.7 \%$ to $33.2 \%$; simultaneously, the ratios of the Chlorophyta increased gradually from $17.5 \%$ to $49.2 \%$. These trends may have been caused by the 
removal of nutrients, which agrees with the previous finding from Tlili et al. [47] that micropollutants from wastewater discharge were responsible for changes in community structure. An interesting result is that the ratios of Bacillariophyta in the periphyton biofilms that attached to the artificial aquatic plants (TB) accounted for a mean of $48.5 \%$, and the dominant species were Achnanthes exigua, Gomphonema acuminatum, Cymbella pusilla, Navicula placentula, and Navicula graciloides. The success of diatoms implies that they have highly efficient and adaptable survival mechanisms and growth strategies. Previous studies have found that diatoms were generally regarded as the principal constituent of the primary colonizers in biofilms $[27,48]$.

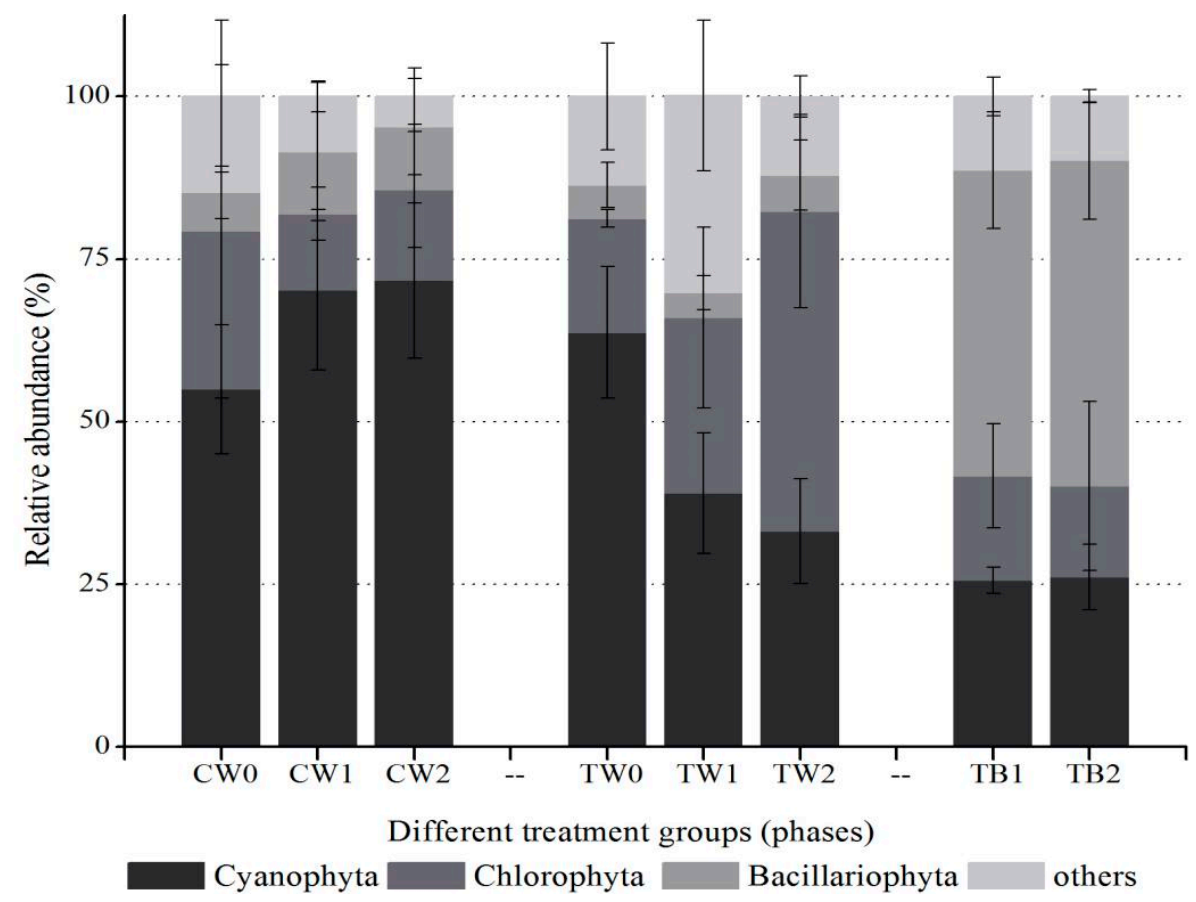

Figure 5. Variation of structural composition of phytoplankton in the enclosure.

\subsection{Dynamics of Bacterial Communities with the Development of Periphyton Biofilms Attached to AAPs}

The structure and succession of the bacterial communities were compared and analyzed during the intervention of the AAPs, which was regarded as an artificial micro-ecosystem where many microorganisms, including new prokaryotic and eukaryotic colonizers, interact in the periphyton biofilms [49]. Gene amplicon sequencing data of samples CW, TW, and TB were acquired based on the $16 S$ rRNA. Due to the usage of fresh substrata (without any microbial community) in the experiment, TB0 (i.e., TB at day zero) was invalid.

In this study, PCoA (Figure 6) revealed that PC 1 and PC 2 explained $53.28 \%$ and $17.41 \%$ of the variation in the bacterial community, respectively. Importantly, TWs were clustered together and were effectively separated from the $(C W)$ samples along PC 1, which was influenced by the decreased concentration of the nutrients of TW adsorbed by the periphyton biofilms attached to the AAPs. Carr et al. [50] reported that bacteria and algae in biofilms coexist in an association that offers space and resources to sustain production of both groups of organisms. Additionally, the heterotrophic bacterial community is an important component of periphyton biofilms and contributes to biodegrade pollutants, the changes in the microbial structure and function in periphyton biofilms exposed to different nutrient supplies [15]. For instance, Suberkropp et al. [51] reported a shift in the microbial structure by the continuous nutrient enrichment of a forested headwater stream. Moreover, TW and TB samples were slightly separated along PC2. This may indicate that the microbial communities of the periphyton biofilms preferred specific adaptable and functional microbes, although TB and TW shared 
the same source of microbial consortia. Therefore, to clarify the changes in the microbial structure in different samples, we considered and analyzed the diversity of the microbial community.

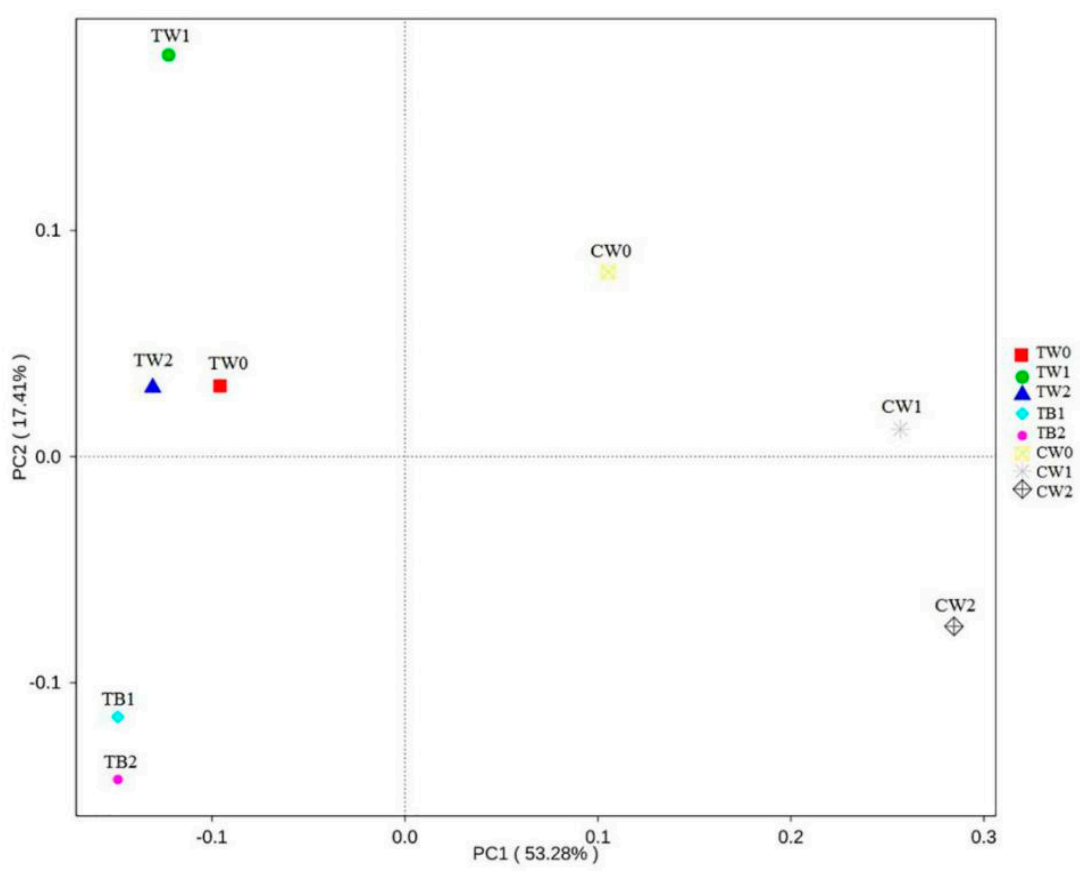

Figure 6. Coordinates analysis (PCoA) based on the weighted UniFrac distance of 16S rRNA genes.

This study chose to detect indices of operational taxonomic unit (OTU) and Shannon and Simpson indices for measuring species diversity and evenness, where a higher value represents greater diversity. The indices of Chao and $\mathrm{ACE}$ are richness estimators, where a higher value represents greater richness, and goods-coverage measures the reliability of the sequencing result.

The results indicate that the bacterial diversity and population richness of TW samples increased gradually, and this is revealed by the Shannon index and Simpson index. The microbial population richness of the TW sample was higher than that of the CW sample after the intervention of the AAPs. Meanwhile, it was indicated that bacterial diversity and population richness of sample TB were quite high and increased gradually as revealed by the Shannon (from 0 up 8.38) and Simpson (from 0 to 0.98) indices (Table 1). The results showed in Figure 7 illustrate the relative abundance of the 10 most abundant bacteria at the phylum level in the CW, TW, and TB samples.

Table 1. Statistics for different treatment samples.

\begin{tabular}{cccccccc}
\hline $\begin{array}{c}\text { Sample } \\
\text { Name }\end{array}$ & $\begin{array}{c}\text { Sequence } \\
\text { Number }\end{array}$ & $\begin{array}{c}\text { OTU } \\
\text { Number }\end{array}$ & $\begin{array}{c}\text { Shannon } \\
\text { Index }\end{array}$ & $\begin{array}{c}\text { Simpson } \\
\text { Index }\end{array}$ & $\begin{array}{c}\text { Chao } \\
\text { Index }\end{array}$ & $\begin{array}{c}\text { ACE } \\
\text { Index }\end{array}$ & Goods-Coverage \\
\hline CW0 & 50,000 & 1764 & 7.774 & 0.984 & 1701.511 & 1745.288 & 0.994 \\
CW1 & 50,874 & 1445 & 6.370 & 0.925 & 1398.249 & 1420.827 & 0.995 \\
CW2 & 44,922 & 1469 & 6.354 & 0.92 & 1512.567 & 2332.759 & 0.987 \\
TW0 & 46,587 & 1672 & 6.764 & 0.969 & 1599.339 & 1649.734 & 0.992 \\
TW1 & 61,178 & 2214 & 8.336 & 0.991 & 2174.538 & 2204.640 & 0.993 \\
TW2 & 54,552 & 2014 & 8.273 & 0.992 & 1913.526 & 1992.917 & 0.993 \\
TB1 & 52,842 & 2056 & 7.856 & 0.968 & 2009.426 & 2033.116 & 0.993 \\
TB2 & 49,478 & 2099 & 8.377 & 0.984 & 2087.237 & 2097.015 & 0.993 \\
\hline
\end{tabular}




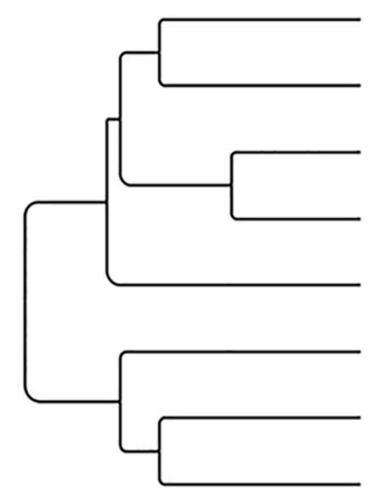

Weighted Unifrac Distance

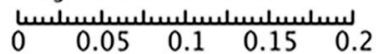

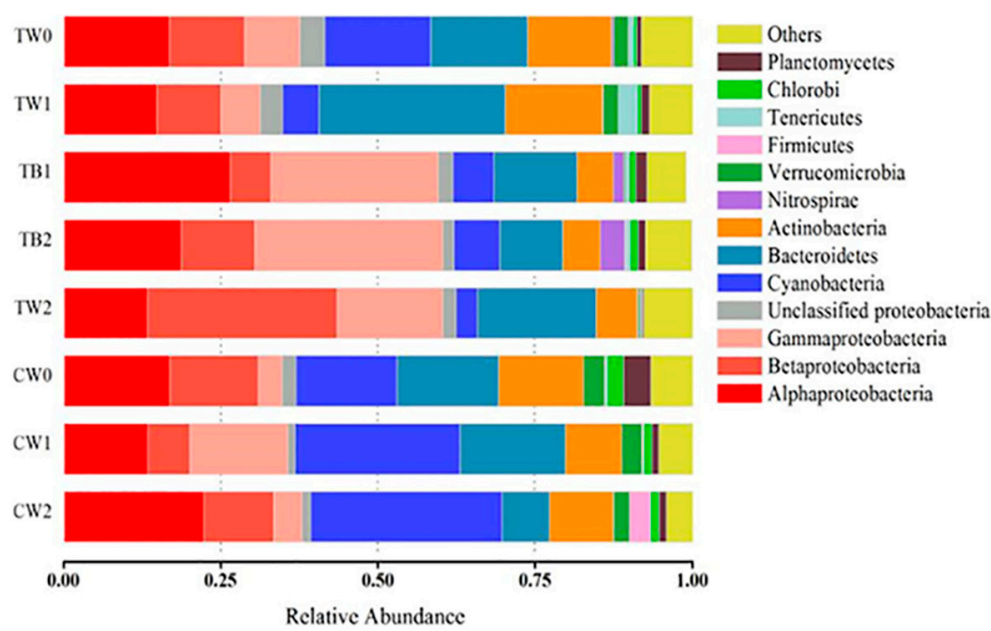

Figure 7. Succession of microbial community during biofilm development at different zones and stages.

Initially, cyanobacteria were found to be one of the dominant prokaryotes in the CW and TW samples. With the incubation of periphyton on AAPs, the relative abundance of cyanobacteria decreased gradually over time in TW, while it increased slightly in CW. This supported the cell fates of Cyanophyta detected by microscopy. Although Proteobacteria were frequently detected in all samples during this experiment, Proteobacteria of the $\alpha$ subdivision (Alphaproteobacteria) dominated in CW and TW, while the $\gamma$ subdivision (Gammaproteobacteria) was dominant in TB. Members of Alphaproteobacteria are known for their biodegradation of COD [52], which explains the coexistence of the high efficiency of COD removal in CW and TW. Gammaproteobacteria were found mainly attached to the membrane module and easily led to biofouling [53,54], which made the microbial community that adhered to the surface of the artificial substrata and benefited from the development of periphyton biofilms. The relative abundance of Nitrospirae increased slowly in the TB, with ratios of $2.79 \%, 0.19 \%$, and $0.02 \%$ in the samples TB, TW, and CW, respectively. Nitrospirae has an autotrophic metabolism and is associated with ammonia-oxidizing strains [55].

\subsection{Restoration of Submerged Macrophytes with Possible Mechanisms}

After 60 days of operation where AAPs were installed in enclosures within Dianchi Lake, the approximately $30 \mathrm{~cm}$ high seedlings of the submerged macrophyte (Elodea nuttallii), which were wrapped with loess clay and nonwoven fabrics, were transplanted into all experimental enclosures at a density of 4 strands $/ \mathrm{m}^{2}$. One month later, the planted E. nuttallii had matured and reached $50 \%$ coverage in treated enclosures while those in control enclosures did not grow. Previous studies have reported that the light compensation depth of submerged macrophytes in Caohai (northern Dianchi Lake) is much lower than the actual water depth, which leads to declines in the submerged macrophytes. The minimum transparency $(0.79 \pm 0.13 \mathrm{~m})$ was required for the restoration of submerged macrophytes at depths of $2 \mathrm{~m} \mathrm{[56].} \mathrm{In} \mathrm{this} \mathrm{study,} \mathrm{the} \mathrm{transparency} \mathrm{in} \mathrm{the} \mathrm{treatment} \mathrm{enclosures} \mathrm{with}$ AAPs increased from the initial $0.6 \pm 0.10 \mathrm{~m}$ to $1.2 \pm 0.10 \mathrm{~m}$ after two months of the experiment, which attained the necessary transparency to restore Elodea nuttallii. Additionally, studies have demonstrated that the occurrence of aquatic macrophyte communities is also related to phytoplankton biomass and certain environmental variables (e.g., COD, nutrients) [57], which suggested the applicability of bioremediation for the restoration of submerged macrophytes.

Given the above, a schematic of mechanisms for improving water quality in shallow eutrophic waters by using AAPs is shown in Figure 8. When an AAP with a large specific surface area was introduced into the eutrophic lake water, large amounts of nutrients (e.g., N, P, and COD), phytoplankton, and planktonic bacteria in the water column were rapidly adsorbed in thousands of microfibers in the AAP to form the periphyton biofilm. Nutrients could then be gradually assimilated by adherent microalgae, and then biodegraded by attached bacteria with the amplification of periphyton 
biofilms. Thus, the reduced availability of nutrients and the competition between the planktonic and attached microbial community led to the restraint of cyanobacterial growth and the subsequent change in planktonic and attached microbial communities. Ultimately, the decrease of nutrients and cyanobacterial biomass in the water column increase the transparency and incident light, thereby facilitating the growth of submerged macrophytes.

\section{Water column

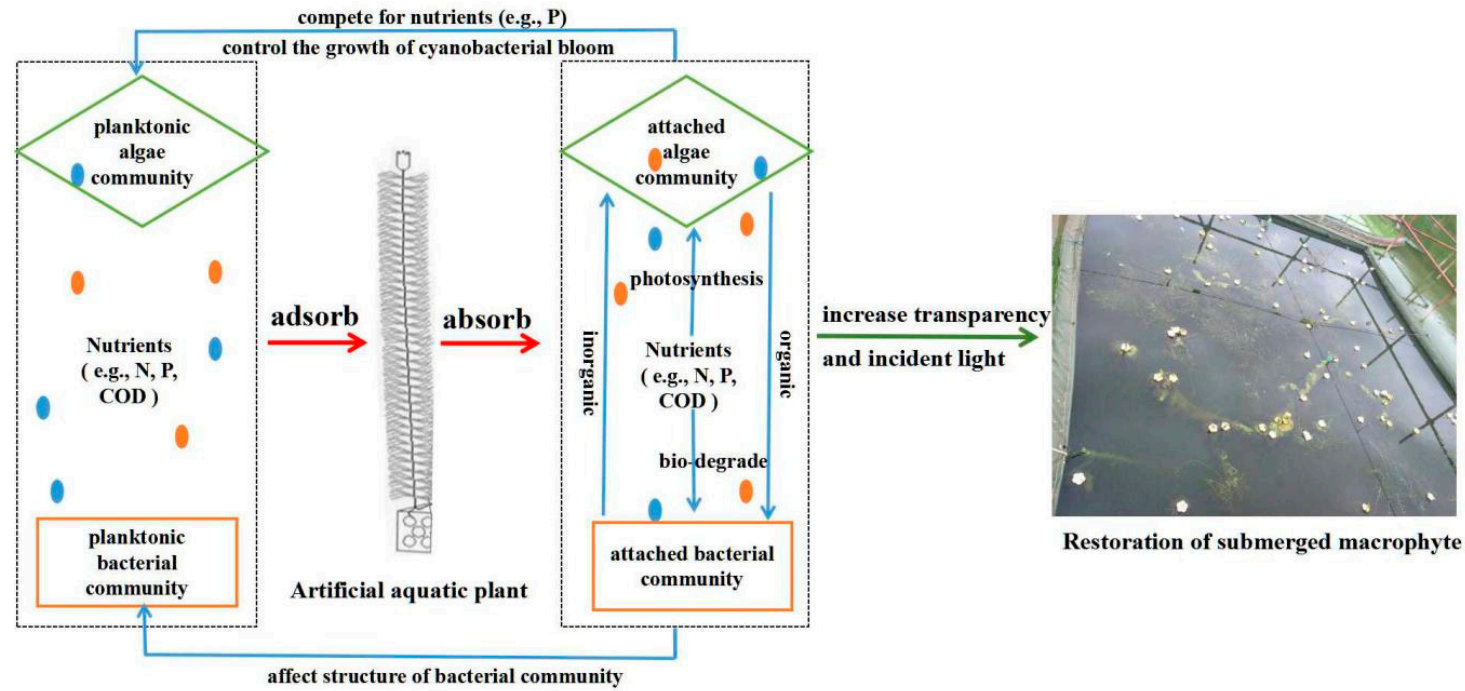

Figure 8. Mechanism of bioremediation for the restoration of submerged macrophytes.

\section{Conclusions}

Introducing the benign bioremediation of AAPs into in situ enclosures of the eutrophic Dianchi Lake for two months was found to reduce nutrient concentrations (both $\mathrm{N}$ and $\mathrm{P}$ ) and phytoplankton biomass in the water column. The results of the increases in TP and Chl $a$ and microbial communities in periphyton biofilms formed on AAPs greatly improved water quality and the subsequent restoration of submerged macrophytes. Management practices targeting periphyton could be potentially used to alleviate the eutrophic waters, which need to be explored further.

Finally, our results reveal the potential importance of AAPs for controlling phytoplankton biomass to promote the growth of submerged macrophytes in shallow eutrophic waters. We anticipate encountering some problems during the transfer of the small-scale experiments reported here to a whole lake situation. Technical problems of exposure and safe remove of thousands AAPs need to be solved. Human interference also needs to be taken into consideration. Long-term and large-scale studies would be of great interest and challenge to evaluate periphyton biofilms attached to AAPs as a transitional means of creating beneficial conditions that control cyanobacterial blooms and restore macrophytes under a complete annual cycle.

Author Contributions: Conceptualization, L.L.; Funding acquisition, L.L. and L.S.; Investigation, Y.W. (Yue Wu), L.H. and Y.W. (Yalin Wang); Methodology, Y.W. (Yue Wu), L.H. and L.L.; Discussion, Y.W. (Yue Wu), L.L., G.L., B.X. and L.S.; Writing-draft preparation, review \& editing, Y.W. (Yue Wu), and L.L.; Project administration, L.L. and L.S.

Funding: This research was funded by the Major Science and Technology Program for Water Pollution Control and Treatment (2013ZX07102005, 2017ZX07203001) and the Joint NSFC-ISF Research Program (41561144008). The APC was funded by the National Key R\&D Program of China (2017YFE0125700).

Acknowledgments: We are grateful to Chunbo Wang, Qichao Zhou, and Xingqiang Wu, for their efficient technical assistance during field and laboratory experiments and thank Eldon R. Rene (UNESCO-IHE) for his comments on the manuscript.

Conflicts of Interest: The authors declare no conflict of interest. 


\section{References}

1. Carpenter, S.R.; Lodge, D.M. Effects of submersed macrophytes on ecosystem processes. Aquat. Bot. 1986, 26, 341-370. [CrossRef]

2. Maberly, S.C. Ecology of Shallow Lakes; Marten Scheffer, Chapman \& Hall: London, UK, 1998; 357p, ISBN 0-412-74920-3.

3. Gulati, R.D.; Donk, E. Biomanipulation in the Netherlands: Applications in fresh water ecosystems and estuarine water-An introduction. Hydrobiol. Bull. 1989, 23, 1-4. [CrossRef]

4. Hosper, S.H. Biomanipulation, new perspective for restoring shallow, eutrophic lakes in The Netherlands. Hydrobiol. Bull. 1989, 23, 11-19. [CrossRef]

5. Scheffer, M.; Hosper, S.H.; Meijer, M.L.; Moss, B.; Jeppesen, E. Alternative equilibria in shallow lakes. Trends Ecol. Evol. 1993, 8, 275-279. [CrossRef]

6. Waters, M.N.; Schelske, C.L.; Brenner, M. Cyanobacterial dynamics in shallow Lake Apopka (Florida, USA) before and after the shift from a macrophyte-dominated to a phytoplankton-dominated state. Freshwater Biol. 2015, 60, 1571-1580. [CrossRef]

7. Smith, V.H. Low Nitrogen to phosphorus ratios favor dominance by blue-green algae in lake phytoplankton. Science 1983, 221, 669-671. [CrossRef]

8. Paerl, H.W.; Huisman, J. Climate change: A catalyst for global expansion of harmful cyanobacterial blooms. Environ. Microbiol. 2009, 1, 27-37. [CrossRef]

9. Waters, M.N.; Piehler, M.F.; Smoak, J.M.; Martens, C.S. The development and persistence of alternative ecosystem states in a large, shallow lake. Freshwater Biol. 2010, 55, 1249-1261. [CrossRef]

10. Brock, T.C.M.; Bongaerts, M.C.M.; Heijnen, G.J.M.A.; Heijthuijsen, J.H.F.G. Nitrogen and phosphorus accumulation and cycling by Nymphoides peltata (Gmel.) O. Kuntze (Menyanthaceae). Aquat. Bot. 1983, 17, 189-214. [CrossRef]

11. Spence, D.H.N. The zonation of plants in freshwater lakes. Adv. Ecol. Res. 1982, 12, 37-125.

12. Wu, Y.H.; Feng, M.Y.; Liu, J.T.; Zhao, Y. Effects of polyaluminium chloride and copper sulfate on phosphorus and UV254 under different anoxic levels. Fresenius Environ. Bull. 2005, 14, 406-412.

13. Stüben, D.; Walpersdorf, E.; Voss, K.; Rönick, H.; Schimmele, M.; Baborowski, M.; Luther, G.; Elsner, W. Application of lake marl at lake Arendsee, NE Germany: First results of a geochemical monitoring during the restoration experiment. Sci. Total Environ. 1998, 218, 33-44. [CrossRef]

14. Hullebusch, E.V.; Deluchat, V.; Chazal, P.M.; Baudu, M. Environmental impact of two successive chemical treatments in a small shallow eutrophied lake: Part I. Case of Aluminium Sulphate. Environ. Pollut. 2002, 120, 617-626. [CrossRef]

15. Chorus, I.; Bartram, J. Toxic Cyanobacteria in Water. A Guide to their Public Health Consequences, Monitoring and Management; F \& FN Spon: London, UK, 1999; p. 416.

16. Larned, S.T. A prospectus for periphyton: Recent and future ecological research. J. N. Am. Benthol. Soc. 2010, 29, 182-206. [CrossRef]

17. Underwood, G.J.C.; Perkins, R.G.; Consalvey, M.C.; Hanlon, A.R.M.; Oxborough, K.; Baker, N.R.; Paterson, D.M. Patterns in Microphyto benthic primary productivity: Species-specific variation in migratory rhythms and photosynthetic efficiency in mixed-species biofilms. Limnol. Oceanogr. 2005, 50, 755-767. [CrossRef]

18. Sukačová, K.; Trtílek, M.; Rataj, T. Phosphorus removal using a microalgal biofilm in a new biofilm photobioreactor for tertiary wastewater treatment. Water Res. 2015, 71, 55-63. [CrossRef] [PubMed]

19. Wan, J.; Liu, X.; Wu, C.; Wu, Y. Nutrient capture and recycling by periphyton attached to modified agrowaste carriers. Environ. Sci. Pollut. Res. 2016, 23, 8035-8043. [CrossRef]

20. Wu, Y.; Zhang, S.; Zhao, H.; Yang, L. Environmentally benign periphyton bioreactors for controlling cyanobacterial growth. Bioresour. Technol. 2010, 101, 9681-9687. [CrossRef]

21. Wu, Y.; Xia, L.; Yu, Z.; Shabbir, S.; Kerr, P.G. In situ bioremediation of surface waters by periphytons. Bioresour. Technol. 2014, 151, 367-372. [CrossRef]

22. Huang, L.C. Ecological Restoration of Eutrophic Lake with Artificial Grass-Take Dianchi Lake for Example. Master's Thesis, Institute of Hydrobiology, Chinese Academy of Sciences, Wuhan, China, June 2016.

23. Prieto, D.M.; Rubinos, D.A.; Piñeiro, V.; Díaz-Fierros, F.; Barral, M.T. Influence of epipsammic biofilm on the biogeochemistry of arsenic in freshwater environments. Biogeochemistry 2016, 129, 291-306. [CrossRef] 
24. Teng, Q.X.; Pang, Y.; Hu, X.Z.; Wang, Y.T.; Huang, T.Y. Application of Artificial Plants in Farmland Drainage Ditches of Boluo River. J. Environ. Eng. Technol. 2016, 6, 65-71.

25. Yang, Y.; Chen, W.; Yi, Z.; Pei, G. The integrative effect of periphyton biofilm and tape grass (Vallisneria natans) on internal loading of shallow eutrophic lakes. Environ. Sci. Pollut. R. 2017, 25, 1773-1783. [CrossRef] [PubMed]

26. He, H.; Luo, X.; Jin, H.; Gu, J.; Jeppesen, E.; Liu, Z.; Li, K. Effects of exposed artificial substrate on the competition between phytoplankton and benthic algae: Implications for shallow lake restoration. Water 2017, 9, 24. [CrossRef]

27. Liu, Y.; Chen, W.; Li, D.; Shen, Y.; Li, G.; Liu, Y. First report of aphantoxins in China-Water blooms of toxigenic Aphanizomenon flos-aquae in Lake Dianchi. Ecotoxicol. Environ. Saf. 2006, 65, 84-92. [CrossRef] [PubMed]

28. Wang, J.H.; Yang, C.; He, L.Q.S.; Dao, G.H.; Du, J.S.; Han, Y.P.; Hu, H.Y. Meteorological factors and water quality changes of Plateau Lake Dianchi in China (1990-2015) and their joint influences on cyanobacterial blooms. Sci. Total Environ. 2019, 665, 406-418. [CrossRef] [PubMed]

29. Liu, L.; Du, R.; Zhang, X.; Dong, S.; Sun, S. Succession and seasonal variation in epilithic biofilms on artificial reefs in culture waters of the sea cucumber Apostichopus japonicus. Chin. J. Ocean. Limnol. 2016, 35, 132-152. [CrossRef]

30. SEPA. Standard Methods for Water and Wastewater Monitoring and Analysis, 4th ed.; State Environmental Protection Administration: Beijing, China, 2002. (In Chinese)

31. APHA. Standard Methods for the Examination of Water and Wastewater, 20th ed.; American Public Health Association: Washington, DC, USA, 1998.

32. Hu, H.; Wei, Y. The Freshwater Algae of China: Systematics, Taxonomy and Ecology; Science Press: Beijing, China, 2006; 1023p.

33. Riis, V.; Lorbeer, H.; Babel, W. Extraction of Microorganisms from Soil: Evaluation of the Efficiency by Counting Methods and Activity Measurements. Soil Biol. Biochem. 1998, 30, 1573-1581. [CrossRef]

34. Nusch, E.A. Comparison of different methods for chlorophyll and phaeopigments determination. Arch. Hydrobiol. Beih. Ergebn. Limnol. 1980, 14, 14-36.

35. Rao, C.R.M.; Reddi, G.S. Decomposition procedure with aqua regia and hydrofluoric acid at room temperature for the spectrophotometric determination of phosphorus in rocks and minerals. Analyt. Chim. Acta 1990, 237, 251-252. [CrossRef]

36. Kunii, H. Characteristics of the winter growth of detached Elodea nuttallii (planch.) St John in Japan. Aquat. Bot. 1981, 11, 57-66. [CrossRef]

37. Kunii, H. Seasonal growth and profile structure development of Elodea nuttallii in pond Ojaga-Ike, Japan (Planch.) St John. Aquat. Bot. 1984, 18, 239-247. [CrossRef]

38. Caporaso, J.G.; Kuczynski, J.; Stombaugh, J.; Bittinger, K.; Bushman, F.D.; Costello, E.K.; Knight, R. QIIME allows analysis of high-throughput community sequencing data. Nat. Med. 2010, 7, 335-336. [CrossRef] [PubMed]

39. Jiang, L.L.; Zhou, L.; Li, S.M.; Fang, G.F. Nutrient removal and microbial community structure in hybrid biofilm reactor. Chin. J. Ophthalmol. 2012, 48, 24-27.

40. Sukačová, K.; Kočí, R.; Žídková, M.; Vítěz, T.; Trtílek, M. Novel insight into the process of nutrients removal using an algal biofilm: The evaluation of mechanism and efficiency. Int. J. Phytoremediat. 2017, 19, 909-914. [CrossRef] [PubMed]

41. Romaní, A.M.; Giorgi, A.; Acuña, V.; Sabater, S. The influence of substratum type and nutrient supply on biofilm organic matter utilization in streams. Limnol. Oceanogr. 2004, 49, 1713-1721. [CrossRef]

42. McCormick, P.V.; Shuford, R.B.E.; Chimney, M.J. Periphyton as a potential phosphorus sink in the Everglades Nutrient Removal Project. Ecol. Eng. 2006, 27, 279-289. [CrossRef]

43. Chiou, R.J.; Yang, Y.R. An evaluation of the phosphorus storage capacity of an anaerobic/aerobic sequential batch biofilm reactor. Bioresour. Technol. 2008, 99, 4408-4413. [CrossRef] [PubMed]

44. Hickman, J.W.; Tifrea, D.F.; Harwood, C.S. A chemosensory system that regulates biofilm formation through modulation of cyclic diguanylate levels. Proc. Nat. Acad. Sci. USA 2005, 102, 14422-14427. [CrossRef] [PubMed] 
45. Li, S.; Wang, C.; Qin, H.; Li, Y.; Zheng, J.; Peng, C.; Li, D. Influence of phosphorus availability on the community structure and physiology of cultured biofilms. J. Environ. Sci. 2016, 42, 19-31. [CrossRef] [PubMed]

46. Spencer, D.F.; Linquist, B.A. Reducing rice field algae and cyanobacteria abundance by altering phosphorus fertilizer applications. Paddy Water Environ. 2013, 12, 147-154. [CrossRef]

47. Tlili, A.; Hollender, J.; Kienle, C.; Behra, R. Micropollutant-induced tolerance of in situ periphyton: Establishing causality in wastewater-impacted streams. Water Res. 2017, 111, 185-194. [CrossRef] [PubMed]

48. Artigas, J.; Fund, K.; Kirchen, S.; Morin, S.; Obst, U.; Romaní, A.M.; Schwartz, T. Patterns of biofilm formation in two streams from different bioclimatic regions: Analysis of microbial community structure and metabolism. Hydrobiologia 2012, 695, 83-96. [CrossRef]

49. Joint, I.; Tait, K.; Wheeler, G. Cross-kingdom signalling: Exploitation of bacterial quorum sensing molecules by the green seaweed Ulva. Philos. Trans. R. Soc. Lond. Ser. B Biol. Sci. 2007, 362, 1223-1233. [CrossRef] [PubMed]

50. Carr, G.M.; Morin, A.; Chambers, P.A. Bacteria and algae in stream periphyton along a nutrient gradient. Freshwater Biol. 2005, 50, 1337-1350. [CrossRef]

51. Suberkropp, K.; Gulis, V.; Rosemond, A.D.; Benstead, J.P. Ecosystem and physiological scales of microbial responses to nutrients in a detritus-based stream: Results of a 5-year continuous enrichment. Limnol. Oceanogr. 2009, 55, 149-160. [CrossRef]

52. Gao, X.Y.; Xu, Y.; Liu, Y.; Liu, Y.; Liu, Z.P. Bacterial diversity, community structure and function associated with biofilm development in a biological aerated filter in a recirculating marine aquaculture system. Mar. Biol. 2011, 42, 1-11. [CrossRef]

53. Atabek, A.; Camesano, T.A. Atomic force microscopy study of the effect of lipopolysaccharides and extracellular polymers on adhesion of Pseudomonas aeruginosa. J. Bacteriol. 2007, 189, 8503-8509. [CrossRef] [PubMed]

54. Gao, D.W.; Wang, X.L.; Xing, M. Dynamic variation of microbial metabolites and community involved in membrane fouling in A/O-MBR. J. Memb. Sci. 2014, 458, 157-163. [CrossRef]

55. Martiny, A.C.; Albrechtsen, H.J.; Arvin, E.; Molin, S. Identification of bacteria in biofilm and bulk water samples from a nonchlorinated model drinking water distribution system: Detection of a large nitrite-oxidizing population associated with Nitrospira spp.. Appl. Environ. Microbiol. 2005, 71, 8611-8617. [CrossRef]

56. Ren, J.C.; Zhou, H.; Sun, Y.T. Vertical distribution of light intensity and light compensation depth of submerged macrophyte in Lake Dianchi. Acta Scicentiarum Nat. Univ. Pekin. 1997, 2, 211-214. (In Chinese)

57. Feldmann, T.; Nõges, P. Factors controlling macrophyte distribution in large shallow Lake Võrtsjärv. Aquat. Bot. 2007, 87, 15-21. [CrossRef]

(C) 2019 by the authors. Licensee MDPI, Basel, Switzerland. This article is an open access article distributed under the terms and conditions of the Creative Commons Attribution (CC BY) license (http://creativecommons.org/licenses/by/4.0/). 